\title{
Use of Statistical Parameters in the Sedimentological Study of Conglomerate Deposits in Northeastern Part of Akwa Ibom State, Niger Delta Basin, Nigeria
}

\author{
Udo, I. G. ${ }^{1}$, Mode, A. W. ${ }^{2}$ \\ ${ }^{I}$ Department of Geology, University of Nigeria, Nsukka, Nigeria. \\ ${ }^{2}$ Depatment of Geology, University of Nigeria, Nsukka, Nigeria.
}

\begin{abstract}
Conglomerates and pebbly sandstone abound along a belt of about 50km long and $11 \mathrm{~km}$ wide in northeastern part of Akwa Ibom State. Granulometric analysis of 29 samples show the deposits to be poorly to moderately sorted, having sorting coefficient values ranging between $0.63 \phi$ to $1.41 \phi$. Pebble morphometric analysis of the conglomerates showed that the mean values of the various morphometric parameters range as follows: flatness ratio $(S / L=0.39-0.58)$, elongation ratio $(I / L=0.64-0.78)$, maximum projection sphericity $(\Psi P$ $=0.60-0.77)$, Oblate Prolate index $(\bar{O} P=-1.98$ to 4.13), coefficient of flatness (39.25-57.86). Roundness index determined for the pebbles through simple comparism with Power's (1953) roundness chart averaged 0.232. Interpretation of pebble morphometric and granulometric results indicate a fluvial environment of deposition for the deposits.
\end{abstract}

Keywords: Conglomerate, deposit, environment, fluvial, roundness

\section{Introduction}

A belt of conglomerate showing a northwest-southeast trend covers an area of about $550 \mathrm{~km}^{2}$ in northeastern part of Akwa Ibom State. The Conglomerate deposits cut across Itu, Ini, Ikono, Ibiono Ibom, Uyo and Uruan Local Government Areas of Akwa Ibom State. The environment of deposition of the deposits has been controversial. Amajor (1986) studied the conglomerate deposit in Itu Local Government Area of the State and interpreted the deposits to be of alluvial fan origin. Petters (1989) also worked on the conglomerate deposit in Itu and Ikono Local Government Areas of the State and suggested a beach environment (marginal marine setting) for the deposits. However, there is no regional view of the conglomerate deposits. The aim of this work is to determine the depositional setting of the conglomerate deposits based on regional study.

\section{Geology of the Study Area}

The study area is bounded by Longitude $7^{0} \quad 40^{1} \mathrm{E}-8^{0} \quad 00^{1} \mathrm{E}$ and Latitude $5^{0} \quad 01^{1} \mathrm{~N}-5^{0} \quad 30^{1} \mathrm{~N}$. Stratigraphically, the deposits belong to Ameki Formation. Reyment (1965) described Ameki Formation as a series of highly fossiliferous grey-green sandy clays with calcareous concretions and white clayey sandstones. The lower part consists of fine to coarse sandstones and intercalations of calcareous shale and thin, shelly limestone, the upper with coarse, cross-bedded sandstones, bands of fine sandstones and sandy clays. It is locally rich in Molluscs, foraminifera and Ostracods. Lithologically, Ameki Formation is very heterogeneous (Wilson, 1925; Reyment, 1965; Adegoke, 1969). Arua and Rao, 1986 noted the presence of pebbles in Ameki Formation. Agagu et. al (1985) and Petters (1978) have interpreted the Ameki Formation to be Estuarine, Lagoon and open marine setting. The Ameki Group consists of the Nanka sand, Nsugbe Formation and Ameki Formation (Nwajide, 1979). The Formation has been considered to be either Early Eocene (Reyment, 1965) or early to Middle Eocene (Berggren, 1960; Adegoke, 1969) and deposited in estuarine, lagoonal and open marine environment content. White (1926) assigned an estuarine environment because of the presence of fish species of known estuarine affinity. Adegoke (1969), however, indicated that the fish were probably washed into the Ameki sea from inland waters, and preferred an open marine depositional environment. Nwajide (1979) and Arua (1986) suggested environments that ranged from nearhore (barrier ridge-lagoonal complex) to intertidal and subtidal zones of the shelf environment, whereas Fayose and Ola (1990) suggested that the sediments were deposited in marine waters between the depth of $10 \mathrm{~m}$ to $100 \mathrm{~m}$. According to Nwajide and Reijers (1996), the progradational Nanka Formation marks the return to regressive conditions. The outcropping deposits of the Eocene regression, which marks the beginning of the Niger Delta progradation, constitute the Ameki Group, which include the tidal facies and backshores as well as pro-delta facies. The prograding shoreface and river deposits are reflected in the subsurface deposits of Agbada Formation in the Northern depobelts of the Niger Delta. 


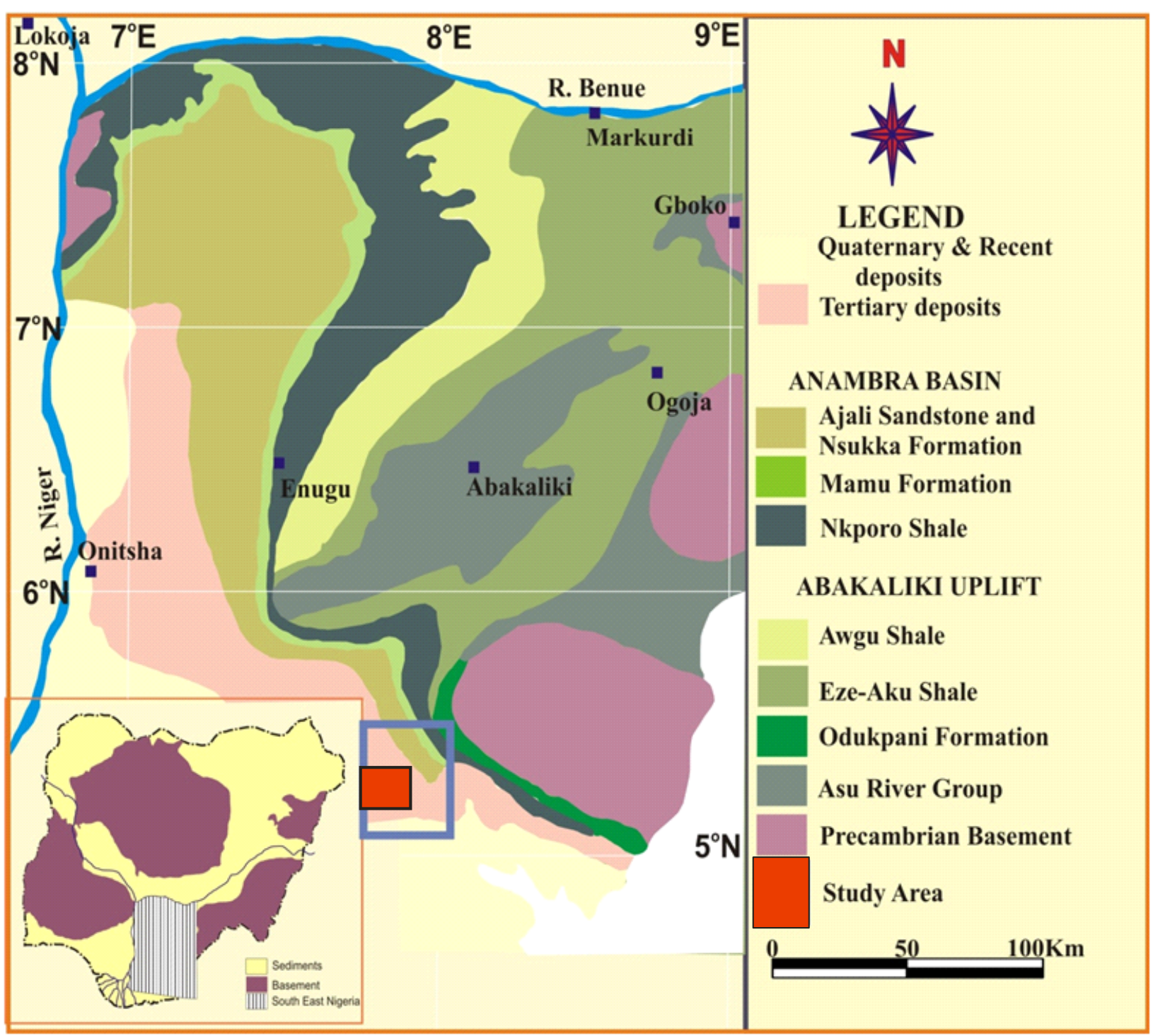

fig.1. geological map showing the study area

\section{Methodology}

Representative samples of the various lithologic units were collected from outcrops in the study area. Each was disaggregated and sieved through $4 \mathrm{~mm}$ screen to separate the gravels from sand for pebble morphometric analysis and granulometric analysis respectively. Computation of maximum projection sphericity $(\Psi \mathrm{P})$, Oblate Prolate index ( $\overline{\mathrm{O}} \mathrm{P})$, coefficient of flatness, inclusive graphic skewness, inclusive graphic standard deviation, graphic kurtosis, and mean grain size were done using appropriate formulae. Qualitative estimate of the Roundness of the pebbles was noted through simple comparison with Power Roundness chart (After Power,1953).

\section{Result}

The mean values of the various morphometric parameters range as follows: flatness ratio $(\mathrm{S} / \mathrm{L}=0.39$ 0.58 ), elongation ratio ( $\mathrm{I} / \mathrm{L}=0.64-0.78)$, maximum projection sphericity ( $\Psi \mathrm{P}=0.60-0.77)$, Oblate Prolate index $(\overline{\mathrm{O}} \mathrm{P}=-1.98$ to 4.13$)$, coefficient of flatness (39.25-57.86), roundness $=0.232$ (TABLE 1). Considering the mean geometric forms, $72 \%$ of the samples were bladed, $22 \%$ were compact bladed and $6 \%$ were compact elongate (TABLE 1).

From the granulometric results of 29 samples (TABLE 2), the skewness values indicate that $62.1 \%$ of the samples are positively skewed, $27.6 \%$ are symmetrical, while $10.3 \%$ are negatively skewed. The kurtosis values indicate that $31 \%$ of the samples are leptokurtic, $38 \%$ mesokurtic and $31 \%$ platykurtic. Sorting values indicate that $96.6 \%$ of the samples are poorly sorted while $3.4 \%$ is moderately sorted. 
Use Of Statistical Parameters In The Sedimentological Study Of Conglomerate Deposits In

TABLE 1: Mean Values of Pebbles Measured

\begin{tabular}{|c|c|c|c|c|c|c|c|c|}
\hline $\begin{array}{l}\text { SAMPLE } \\
\text { NUMBER }\end{array}$ & $\frac{I}{L}$ & $\frac{S}{L}$ & $\frac{L-I}{L-S}$ & $\Psi P$ & $\overline{\mathbf{O}} \overline{\mathbf{P}}$ & $\begin{array}{l}\text { COEFFICIENT } \\
\text { OF FLATNESS }\end{array}$ & FORM & $\begin{array}{l}\text { MEAN } \\
\text { ROUNDNESS }\end{array}$ \\
\hline $\mathrm{IN} 25 \mathrm{~S} 2$ & 0.6566 & 0.4779 & 0.6539 & 0.6833 & 3.4550 & 47.78 & $\mathrm{~B}$ & 0.250 \\
\hline IN4S1 & 0.6986 & 0.3935 & 0.5022 & 0.5992 & -0.1503 & 39.25 & $\mathrm{~B}$ & 0.219 \\
\hline IN5S1 & 0.7349 & 0.4755 & 0.5257 & 0.6744 & 0.0816 & 47.55 & B & 0.255 \\
\hline IN8S2 & 0.7411 & 0.4874 & 0.5015 & 0.6842 & -0.1746 & 48.74 & B & 0.223 \\
\hline IN10S3 & 0.7343 & 0.4948 & 0.5289 & 0.6912 & 0.5297 & 49.48 & B & 0.222 \\
\hline IN27S1 & 0.7124 & 0.4060 & 0.4960 & 0.6150 & -0.5458 & 40.60 & $\mathrm{~B}$ & 0.245 \\
\hline IK2S1 & 0.7341 & 0.4709 & 0.5046 & 0.6685 & 0.0680 & 47.09 & $\mathrm{~B}$ & 0.223 \\
\hline$\overline{\mathrm{IB} 7 \mathrm{~S} 1}$ & 0.7728 & 0.5160 & 0.4604 & 0.6958 & 0.7556 & 51.60 & $\mathrm{CB}$ & 0.233 \\
\hline IB12S1 & 0.7691 & 0.4779 & 0.4389 & 0.6648 & -1.3145 & 47.79 & $\mathrm{~B}$ & 0.230 \\
\hline IB8S1 & 0.7316 & 0.4587 & 0.4879 & 0.6601 & -0.0922 & 45.87 & $\mathrm{~B}$ & 0.252 \\
\hline IN12S2 & 0.6737 & 0.4603 & 0.6007 & 0.6792 & 2.3940 & 46.03 & B & 0.222 \\
\hline IN7S1 & 0.6957 & 0.4577 & 0.5531 & 0.6652 & 1.4920 & 45.77 & $\mathrm{~B}$ & 0.223 \\
\hline IN16S2 & 0.7379 & 0.4874 & 0.5193 & 0.6806 & 0.3104 & 48.74 & B & 0.223 \\
\hline IT1S1 & 0.6815 & 0.4720 & 0.6026 & 0.6860 & 2.3569 & 47.20 & B & 0.232 \\
\hline IB4S1 & 0.7210 & 0.5044 & 0.5459 & 0.7044 & 1.1715 & 50.44 & $\mathrm{CB}$ & 0.237 \\
\hline IK1S2 & 0.7207 & 0.4940 & 0.5609 & 0.6934 & 1.1023 & 49.40 & B & 0.236 \\
\hline IB2S1 & 0.6453 & 0.4613 & 0.6694 & 0.6882 & 3.5278 & 46.17 & B & 0.239 \\
\hline IB9S1 & 0.6815 & 0.4537 & 0.5888 & 0.6689 & 1.8027 & 45.37 & $\mathrm{~B}$ & 0.242 \\
\hline IT2S1 & 0.7096 & 0.5166 & 0.6042 & 0.7207 & 2.0755 & 51.66 & CB & 0.244 \\
\hline UR1S1 & 0.6814 & 0.4653 & 0.6040 & 0.6780 & 2.1505 & 46.53 & B & 0.244 \\
\hline IB10S1 & 0.6567 & 0.4563 & 0.6380 & 0.6824 & 3.0401 & 45.63 & B & 0.235 \\
\hline IT5S2 & 0.6984 & 0.4583 & 0.5846 & 0.6652 & 1.4480 & 45.83 & $\mathrm{~B}$ & 0.240 \\
\hline IN26S1 & 0.7066 & 0.4845 & 0.5959 & 0.6983 & 1.8147 & 48.45 & B & 0.230 \\
\hline IB3S1 & 0.7153 & 0.4620 & 0.5151 & 0.6636 & 0.2526 & 46.20 & B & 0.232 \\
\hline UR2S1 & 0.7587 & 0.4263 & 0.4194 & 0.6208 & -1.9848 & 42.63 & $\mathrm{~B}$ & 0.229 \\
\hline UY1S1 & 0.7018 & 0.4516 & 0.5499 & 0.6562 & 1.1273 & 45.16 & B & 0.233 \\
\hline IT4S1 & 0.7051 & 0.4578 & 0.5516 & 0.6746 & 0.9352 & 45.78 & B & 0.247 \\
\hline IB18S1 & 0.6575 & 0.4598 & 0.6327 & 0.6853 & 2.9708 & 45.98 & B & 0.231 \\
\hline IB17S1 & 0.6840 & 0.4746 & 0.6153 & 0.6887 & 2.2032 & 47.46 & B & 0.234 \\
\hline IB16S1 & 0.7064 & 0.4698 & 0.5437 & 0.6762 & 1.2124 & 46.98 & B & 0.239 \\
\hline IB15S1 & 0.7380 & 0.4812 & 0.4929 & 0.6785 & 0.1589 & 48.12 & B & 0.224 \\
\hline IN13S6 & 0.6448 & 0.4187 & 0.6152 & 0.6452 & 2.7881 & 41.87 & B & 0.237 \\
\hline IN14S1 & 0.7565 & 0.4797 & 0.4911 & 0.6701 & -0.6787 & 47.97 & B & 0.238 \\
\hline IN11S4 & 0.7010 & 0.4107 & 0.5213 & 0.6193 & 0.1173 & 41.07 & B & 0.235 \\
\hline IN9S5 & 0.7402 & 0.4696 & 0.4945 & 0.6664 & -0.2126 & 46.96 & B & 0.227 \\
\hline IB5S1 & 0.7176 & 0.4668 & 0.5284 & 0.6698 & 0.6953 & 46.68 & B & 0.231 \\
\hline IN6S1 & 0.7312 & 0.4847 & 0.5351 & 0.6827 & 0.5527 & 48.42 & B & 0.231 \\
\hline IB6S1 & 0.7775 & 0.4879 & 0.4441 & 0.6736 & -1.4001 & 48.79 & B & 0.235 \\
\hline IN1S1 & 0.7119 & 0.4542 & 0.5276 & 0.6620 & 0.6668 & 45.42 & B & 0.230 \\
\hline IN3S6 & 0.7308 & 0.4611 & 0.5073 & 0.6592 & 0.0176 & 46.11 & B & 0.230 \\
\hline IN2S1 & 0.6567 & 0.5157 & 0.7052 & 0.7410 & 4.1315 & 51.57 & $\mathrm{CE}$ & 0.220 \\
\hline IN17S1 & 0.7367 & 0.5428 & 0.5645 & 0.7341 & 1.3996 & 54.28 & $\mathrm{~B}$ & 0.224 \\
\hline $\mathrm{IK} 3 \mathrm{~S} 1$ & 0.6822 & 0.5013 & 0.6417 & 0.7190 & 2.7856 & 50.13 & $\mathrm{CB}$ & 0.223 \\
\hline IN15S1 & 0.7103 & 0.5743 & 0.6945 & 0.7706 & 3.3114 & 57.43 & $\mathrm{CE}$ & 0.217 \\
\hline IT6S2 & 0.6836 & 0.5322 & 0.6853 & 0.7444 & 3.4272 & 53.22 & $\mathrm{CE}$ & 0.226 \\
\hline IT3S4 & 0.7083 & 0.5406 & 0.6316 & 0.7440 & 2.5377 & 54.06 & $\mathrm{CB}$ & 0.224 \\
\hline IB13S5 & 0.7191 & 0.5529 & 0.6286 & 0.7504 & 2.4204 & 55.29 & CB & 0.227 \\
\hline IB14S2 & 0.7136 & 0.5467 & 0.6258 & 0.7424 & 2.4082 & 54.67 & CB & 0.225 \\
\hline IB11S2 & 0.7710 & 0.5786 & 0.5467 & 0.7542 & 0.7908 & 57.86 & $\mathrm{CB}$ & 0.221 \\
\hline IB20S2 & 0.7391 & 0.5515 & 0.5803 & 0.7437 & 1.4694 & 55.15 & $\mathrm{CB}$ & 0.224 \\
\hline
\end{tabular}


Use Of Statistical Parameters In The Sedimentological Study Of Conglomerate Deposits In

TABLE 2. Grain Size Parameters

\begin{tabular}{|c|c|c|c|c|c|c|c|c|c|c|c|c|}
\hline SAMPLE & $\Phi 5$ & $\Phi 16$ & $\Phi 25$ & $\Phi 50$ & $\Phi 75$ & $\Phi 84$ & $\Phi 95$ & $\mathrm{Mz}$ & $\sigma_{1}$ & $\mathrm{SK}_{1}$ & $\mathrm{KG}$ & REMARK \\
\hline IB6S1 & -0.85 & -0.42 & -0.20 & 0.50 & 1.38 & 1.60 & 2.30 & 0.56 & 0.98 & 0.12 & 0.82 & MS,PK,P \\
\hline IN7S1 & -0.66 & -0.27 & -0.05 & 0.57 & 1.30 & 1.65 & 2.35 & 0.65 & 0.94 & 0.15 & 0.91 & MS,PK,M \\
\hline IN4S5 & -0.94 & -0.40 & -0.05 & 0.60 & 1.00 & 1.58 & 2.45 & 0.59 & 1.01 & 0.04 & 1.32 & $\mathrm{PS}, \mathrm{S}, \mathrm{L}$ \\
\hline IB8S1 & -0.68 & -0.12 & 0.20 & 1.10 & 2.05 & 2.40 & 3.30 & 1.13 & 1.23 & 0.07 & 0.88 & PS,S,P \\
\hline IN6S1 & -0.91 & -0.40 & -0.15 & 0.66 & 1.68 & 2.15 & 3.20 & 0.80 & 1.26 & 0.20 & 0.92 & PS,PK,M \\
\hline IB2S2 & -0.64 & -0.05 & 0.40 & 1.15 & 1.50 & 1.80 & 2.43 & 0.97 & 0.93 & -0.23 & 1.14 & $\mathrm{MS}, \mathrm{NK}, \mathrm{L}$ \\
\hline IN16S2 & -0.80 & -0.42 & -0.21 & 0.35 & 1.15 & 1.50 & 2.25 & 0.48 & 0.94 & 0.22 & 0.92 & $\mathrm{MS}, \mathrm{PK}, \mathrm{M}$ \\
\hline IB5S1 & -0.95 & -0.21 & 0.10 & 0.60 & 1.25 & 1.55 & 2.10 & 0.65 & 0.90 & 0.03 & 1.09 & $\mathrm{MS}, \mathrm{S}, \mathrm{M}$ \\
\hline IB14S2 & -0.7 & -0.37 & -0.15 & 0.60 & 1.50 & 1.90 & 2.80 & 0.71 & 1.10 & 0.20 & 0.87 & PS,PK,P \\
\hline IN25S2 & -0.93 & -0.30 & 0.00 & 0.64 & 1.30 & 1.65 & 2.30 & 0.66 & 0.98 & 0.03 & 1.02 & $\mathrm{MS}, \mathrm{S}, \mathrm{M}$ \\
\hline IN10S3 & -0.80 & -0.43 & -0.25 & 0.18 & 0.76 & 1.00 & 2.00 & 0.25 & 0.78 & 0.22 & 1.14 & MS,PK,L \\
\hline IN14S1 & -0.63 & -0.33 & -0.18 & 0.40 & 0.89 & 1.40 & 2.64 & 0.49 & 0.93 & 0.26 & 1.25 & MS,PK,L \\
\hline IN2S2 & -0.63 & 0.04 & 0.38 & 0.84 & 1.57 & 1.84 & 2.89 & 0.91 & 0.98 & 0.14 & 1.21 & MS,PK,L \\
\hline IK4S1 & -0.20 & 0.30 & 0.45 & 0.88 & 1.35 & 1.65 & 2.45 & 0.94 & 0.74 & 0.16 & 1.21 & MS,PK,L \\
\hline IN26S1 & -0.98 & -0.46 & -0.20 & 0.40 & 1.30 & 1.75 & 2.64 & 0.56 & 1.10 & 0.23 & 0.99 & PS,PK,M \\
\hline IN1S2 & -0.97 & -0.50 & -0.30 & 0.40 & 1.39 & 2.16 & 2.75 & 0.69 & 1.23 & 0.29 & 0.90 & PS,PK,M \\
\hline IT5S3 & -0.64 & -0.37 & -0.20 & 0.38 & 1.10 & 1.40 & 2.25 & 0.47 & 0.88 & 0.22 & 0.91 & $\mathrm{MS}, \mathrm{PK}, \mathrm{M}$ \\
\hline UR2S1 & -0.45 & 0.55 & 1.20 & 2.60 & 3.10 & 3.24 & 3.48 & 2.13 & 1.27 & -0.54 & 0.85 & PS,VNK,P \\
\hline IT3S4 & 0.15 & 0.43 & 0.59 & 1.05 & 1.50 & 1.72 & 2.17 & 1.07 & 0.63 & 0.07 & 0.91 & MWS,S,M \\
\hline IB13S5 & -0.93 & -0.35 & -0.05 & 0.65 & 1.50 & 2.10 & 3.14 & 0.80 & 1.23 & 0.20 & 1.08 & PS,PK,M \\
\hline IB7S1 & -0.87 & -0.42 & 0.03 & 0.82 & 1.50 & 1.65 & 1.98 & 0.68 & 0.95 & -0.19 & 0.79 & $\mathrm{MS}, \mathrm{NK}, \mathrm{P}$ \\
\hline IN17S1 & -0.77 & -0.27 & 0.00 & 0.94 & 2.25 & 2.80 & 3.50 & 1.16 & 1.41 & 0.21 & 0.78 & PS,PK,P \\
\hline IN8S2 & -0.92 & -0.39 & -0.10 & -0.60 & 1.14 & 1.54 & 2.50 & 0.18 & 1.00 & 1.02 & 1.13 & PS,PK,L \\
\hline IK2S1 & -0.66 & -0.19 & 0.00 & 0.86 & 1.64 & 1.93 & 2.60 & 0.87 & 1.02 & 0.04 & 0.81 & PS,S,P \\
\hline IN12S6 & -0.92 & -0.35 & 0.05 & 0.70 & 1.50 & 2.05 & 3.10 & 0.80 & 1.21 & 0.16 & 1.14 & PS,PK,L \\
\hline IN13S6 & -0.77 & -0.38 & -0.20 & 0.35 & 1.14 & 1.46 & 2.20 & 0.48 & 0.91 & 0.23 & 0.91 & MS,PK,P \\
\hline IB4S1 & -0.85 & -0.25 & -0.10 & 0.80 & 1.40 & 1.64 & 2.27 & 0.73 & 0.95 & -0.08 & 0.85 & MS,S,P \\
\hline UR1S1 & -0.68 & -0.37 & -0.23 & 0.12 & 1.00 & 1.34 & 2.05 & 0.36 & 0.84 & 0.42 & 0.91 & MS,VPK,M \\
\hline IT2S1 & -0.82 & -0.28 & 1.00 & 0.70 & 1.40 & 1.70 & 2.48 & 0.71 & 1.00 & 0.04 & 3.38 & PS,S,EL \\
\hline
\end{tabular}

\section{Legend}

PS - Poorly sorted

MS - Moderately sorted

MWS - Moderately well sorted

PK - Positively skewed

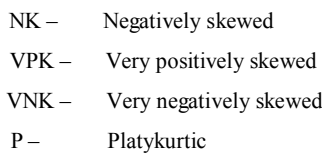

L - $\quad$ Leptokurtic
EL - Extremely leptokurtic
S - Symmetrical
M - Mesokurtic

\section{Discussion}

According to Dobkin and Folk (1970), Gale (1990), particular gravel clasts shape concentrate in particular environments. For example Disc accumulates on beaches while rollers (Elongate clasts) and Bladed accumulate in rivers. From the result (TABLE 1), 72\% of the samples were Bladed, 22\% were compact Bladed, $6 \%$ were compact Elongate. Since the mean geometric form were Bladed, compact Bladed, and compact Elongate (Fig.3), it means that the environment of deposition is likely to be fluviatile.

In a comperative study of gravels obtained from beaches and rivers in Southern Africa, Stratten (1974) found that fluvial pebbles have mean coefficient of flatness of more than 45 and that their mean sphericities exceeds 0.65. Dobkin and Folk (1970), in their study of basalt pebbles in rivers and beaches in Tahiti-Nui, arrived at a lower limit of 0.66 for the mean sphericity of fluvial pebbles, a figure very close to that of stratten (1974). Dobkin and Folk (1970), also found that the mean Oblate-Prolate index of fluvial pebbles exceeds -1.5, whereas the value of beach pebbles is lower. It seems, therefore, that the following values are approximate lower index limits for pebbles shaped in a fluvial environment:

Sphericity

Coefficient of flatness

Oblate-Prolate index
0.65

45

$-1.5$ lower limits for fluvial pebbles thus lending credence to fluvial origin.

Plot of maximum projection sphericity against coefficient of flatness(Fig.2) shows that majority of the points lie in the fluvial field of Stratten (1974).

Bivariate plot of maximum projection sphericity versus Oblate-Prolate index (Fig.4) also shows most of the points plotting within the fluvial realm.

Sames (1966) found that roundness values less than 0.350 are typical of river pebbles whereas values more than 0.450 suggest littoral environment. Dobkin and Folk (1970) established for river and beach pebbles, 
mean roundness values of 0.375 and 0.508 respectively. From these values, it appears that a mean roundness index of 0.380 is the upper limit for pebbles shaped by a river.

The mean roundness value for pebbles in the study area calculated from TABLE 1 is 0.232 . This is well below the critical value of 0.380 for river pebbles.

According to McManus (1995), beach sands are well sorted and negatively skewed while river sands are less well sorted and usually positively skewed. From the granulometric result (TABLE 2), the sorting values indicate that $96.6 \%$ of the samples are poorly sorted while $3.4 \%$ is moderately well sorted. The skewness values indicate that $62.1 \%$ of the samples are positively skewed, $27.6 \%$ are symmetrical, while $10.3 \%$ are negatively skewed. The poorly sorted nature of the samples and the positively skewed nature of most of the samples support fluvial origin.

Bivariate plots of skewness versus sorting (Fig.6) and mean grain size versus sorting (Fig.5) indicate that the environment of deposition is fluvial (Friedman 1967, Moiola and Weiser 1968).

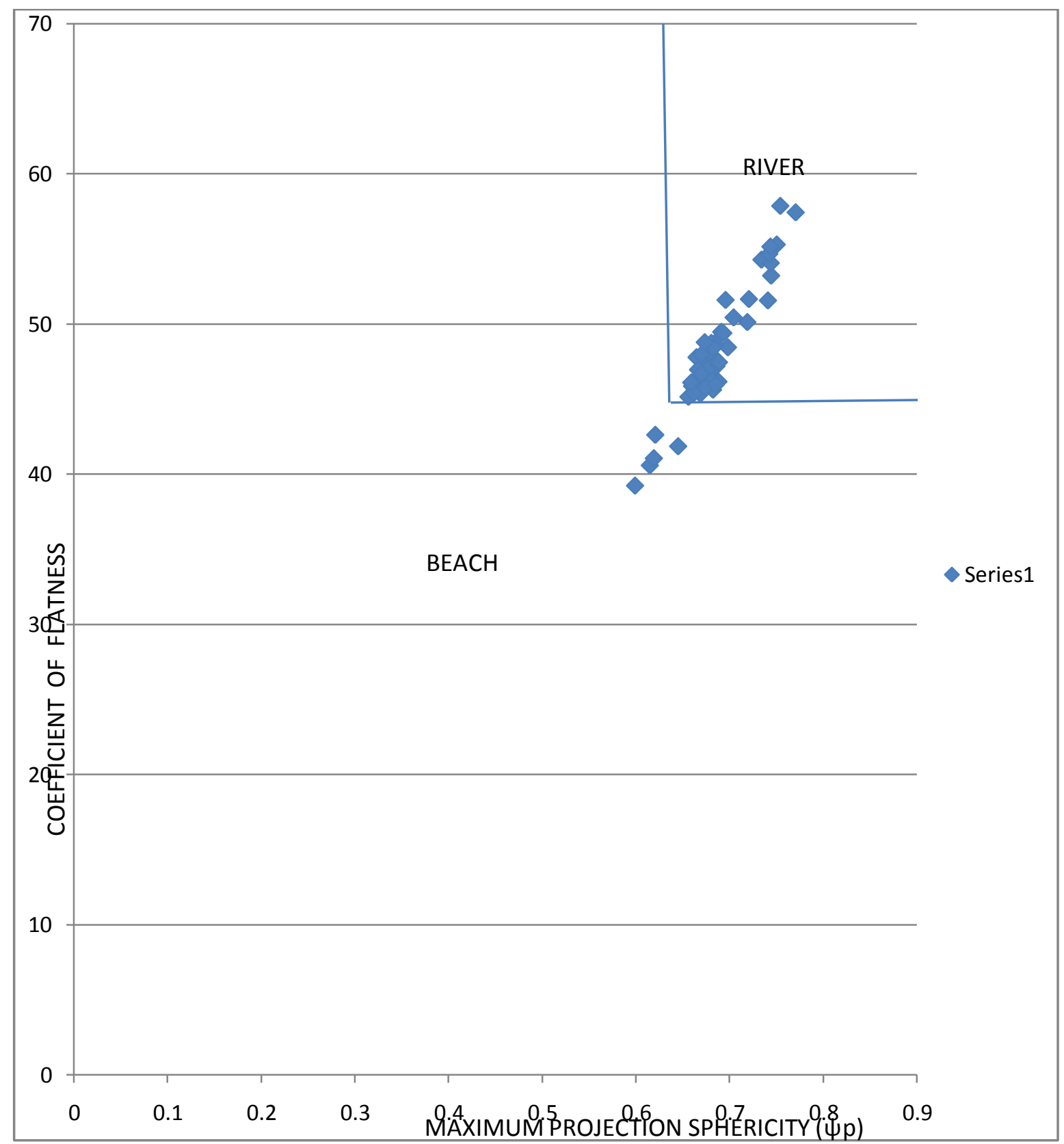

fig.2. plot of coefficient of flatness versus $\psi p$ after Stratten, 1974 


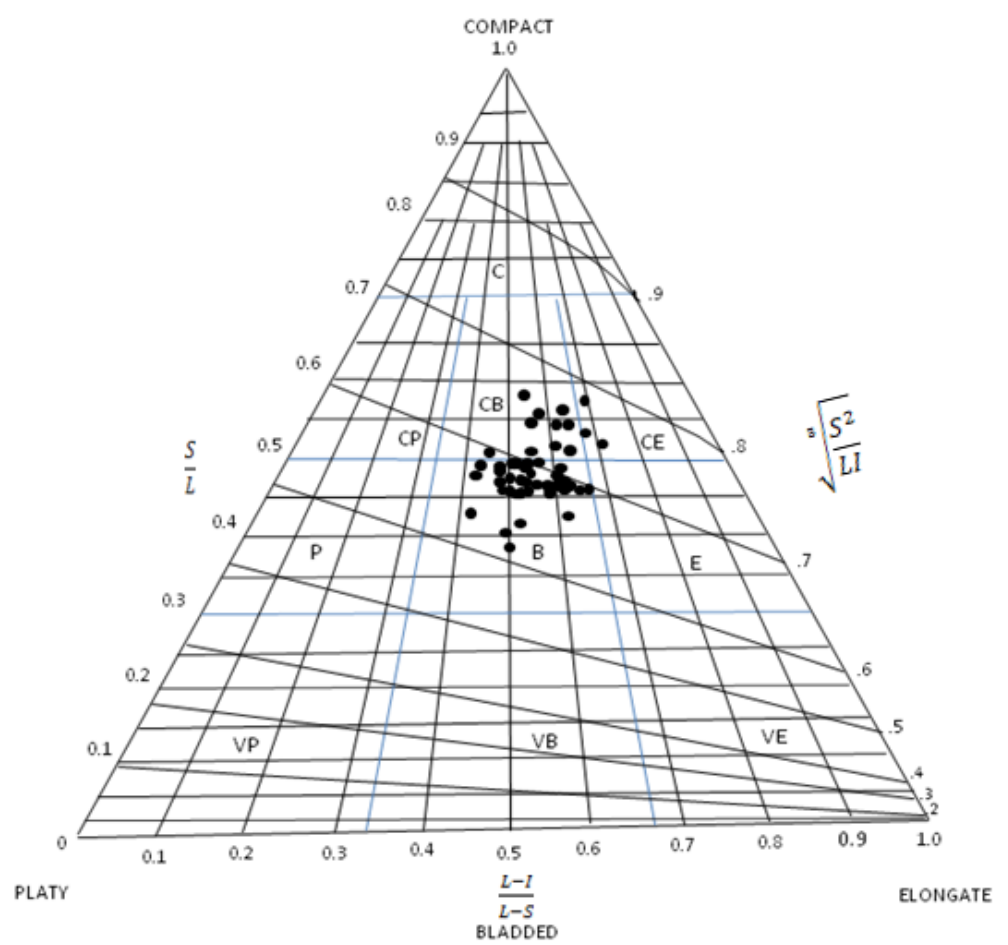

fig. 3. sphericity form diagram after Sneed and Folk (1970). each point is an average of twenty pebbles.

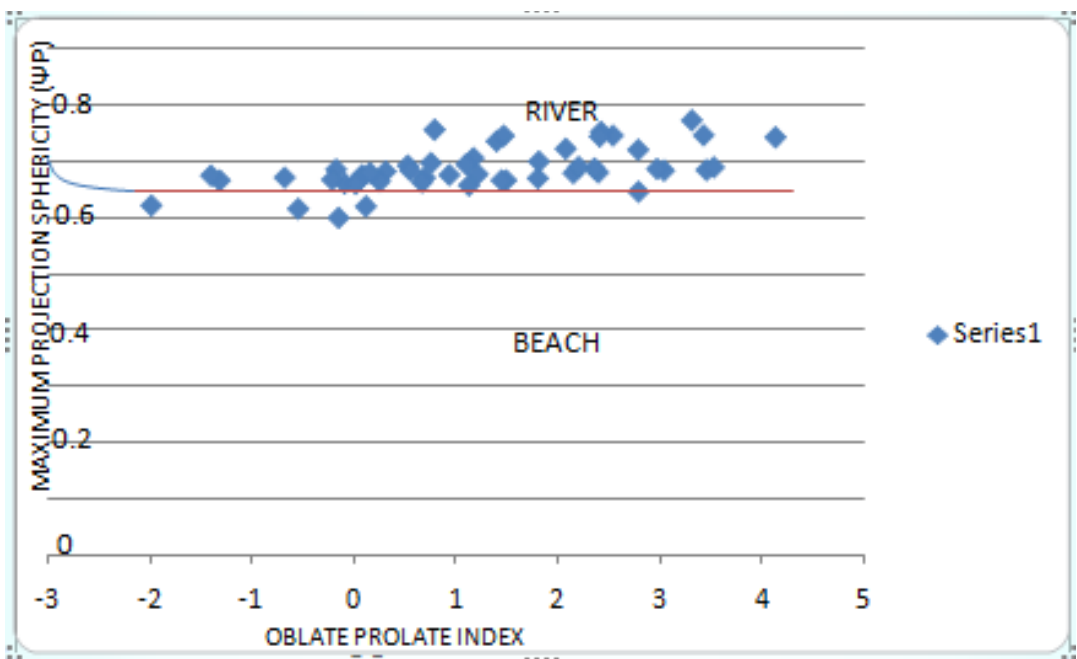

fig. 4. plot of $\psi p$ versus $\overline{\mathrm{O}} \overline{\mathrm{P}}$ after Dobkin and Folk (1970)

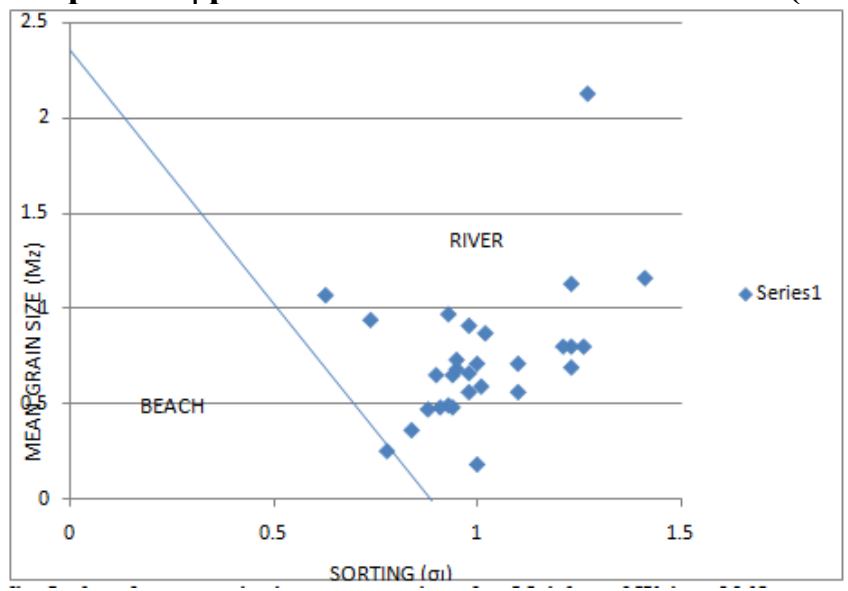

fig. 5. plot of mean grain size versus sorting after Moiola and Weiser, 1968 


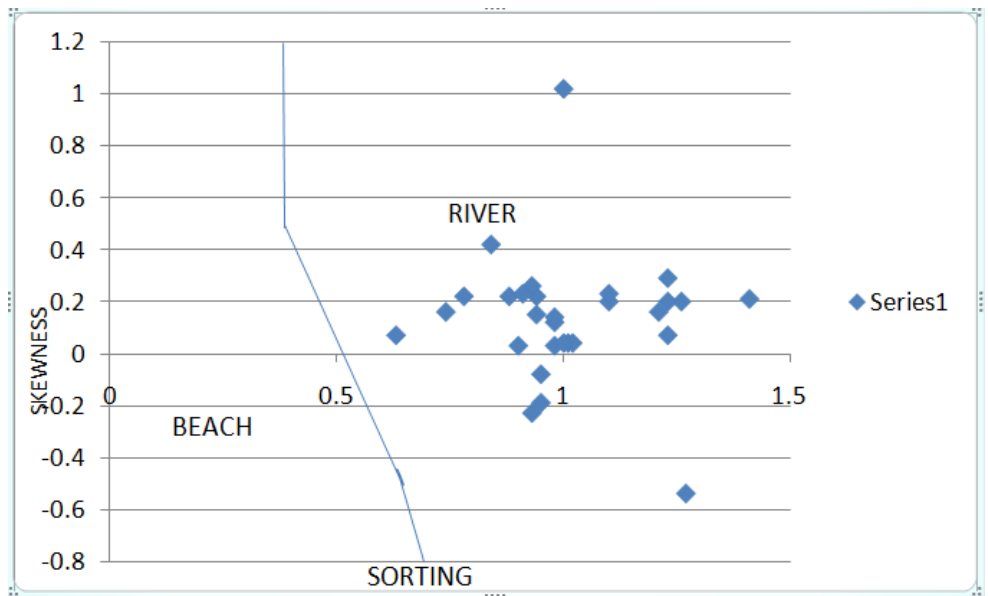

fig. 6. plot of skewness versus sorting after Friedman, 1967

\section{Conclusion}

This study reveals that the conglomerate deposits in Northeastern part of Akwa Ibom State, Niger Delta basin, Nigeria are of fluvial origin.

\section{Acknowledgement}

We are grateful to Udom, G. J. for his helpful comments.

\section{References}

[1]. L. C. Amajor, Alluvial fan Facies in the Miocene-Pliocene coastal plain sand, Niger Delta, Nigeria, Journal of Sedimentary Geology, 49, 1986, 1- 20.

[2]. S. W. Petters, Akwa Ibom State Physical Background, Soils and Land use Ecological Problems, Technical Report of the Task Force on Soil and Land Use Survey, Akwa Ibom State ( Government Printers, Uyo, 1989).

[3]. R. A. Reyment, Aspects of the Geology of Nigeria, (Ibadan University Press, Ibadan, 1965).

[4]. R. C. Wilson, The geology of th Eastern Railway, Section 1, Port Harcourt to Enugu, Geolological Survey of Nigeria Bullettin, 8 $1925,1-95$.

[5]. O. S. Adegoke, Eocene stratigraphy of southern Nigeria, Bull. B. R.G.M. Mem. .69, 1969, 23-48.

[6]. I. Arua, V. R. Rao, New stratigraphic data od Eocene Ameki Formation, Southeastern Nigeria., Journal of African Earth Science, 3, 1986, 1-7.

[7]. O. K. Agagu, E. A. Fayose and S. W. Petters, Stratigraphy and Sedimentation in the Senonian Anambra Basin of Eastern Nigeria, Nigerian Journal of Mining and Geology, 22, 1985, 25-36.

[8]. S. W. Petters, Stratigraphic Evolution of the Benue Trough and its Implications for the Upper Cretaceous Paleogeograhy of West Africa, Journal of Geology, 86, 1978, 311-322.

[9]. C. S. Nwajide, A lithostratigraphic analysis of the Nanka Sands, southeastern Nigeria., Nigerian Journal of Mining and Geology,16, 1979, 103-109.

[10]. W. A. Berggren, Paleocene Biostratigraphy and Planktonic Foraminifera of Nigeria (West Africa), Proc. 21 st Inter. Geol. Cong. Copenhagen, 6, 1960, 41-55.

[11]. E. L. White, Eocene fishes from Nigeria, Bullettin of Geological Survey of Nigeria 10, 1926, 1-82.

[12]. I. Arua, Paleoenvironment of Eocene deposits in Afikpo syncline, southern Nigeria, Journal of African Earth Science, 5, 1986, 279-284.

[13]. E. A. Fayose and P. S. Ola, Radiolarian occurrences in the Ameki type section, eastern Nigeria, Journal of Mining and Geology $26,1990,75-80$.

[14]. C. S. Nwajide and T. J. A. Reijers, Geology of the southern Anambra Basin. In: Reijers, T. J. A. (Ed), selected chapters on geology: Sedimentary geology and sequence stratigraphy of Anambra Basin (SPDC Corporate Reprographic Services, Warri, Nigeria, 1996) 133-148.

[15]. M. C. Power, A New roundness Scale for Sedimentary Particles, Journal of Sedimentary Petrology, 23, 1953, 117-119. Petrol., 23, p. $117-119$.

[16]. J. Dobkins and R. K. Folk, Shape Development on Tahiti-Nui, Journal of Sedimentary Petrology, 40 (4), 1970, 1167-1203.

[17]. S. J. Gale, The Shape of Beach Gravels, Journal of Sedimentary Petrology, 60, 1990, 787-789.

[18]. T. Stratten, Notes on the Apllication of Shape Parameters to Differentiate between Beach and River Deposits in Southern Africa. In: Pebble Morphology of Ancient Conglomerate. The Middlevlei Gold Placer, Witwatersrand, South Africa (ed. B. G. Els), Journal of Sedimentary Petrology, 58, 1974, 894-901.

[19]. C. Sames, Morphometric Data of Some Recent Pebble Association, Journal Sedimentary Petrology, 36. 1966, 126-142.

[20]. J. McManus, Grain Size Determination and Interpretation. In: Techniques in Sedimentology (ed. T. Maurice) (Blackwell Science, 1995) 63-85.

[21]. G. M. Friedman, Dynamic Processes and Statistical parameters compared for size Frequency Distribution of Beach and River Sands, Journal of Sedimentary Petrolology, 37, 1967, 327-354.

[22]. R. J. Moiola, and D. Weiser, Textural Parameters: An Evaluation, Journal of Sedimentary Petrology, 38, 1968, 45- 53.

[23]. E. Sneed and R. Folk, Pebbles in the Lower Clolorado River, Texas: a Study in Particle Morphogenesis, Journal of Geology, 66, $1958,114-150$. 